\title{
Universo Almodóvar: estética de la pasión en un cineasta postmoderno
}

José Luis Sánchez Noriega. Madrid. Alianza Editorial, 2017. 479 páginas.

\section{Reseña por Sofía Otero Escudero.}

http://dx.doi.org/10.12795/AdMIRA.2017.02.07

El arte posmoderno gira en torno a la cultura del consumo, la globalización, la cultura popular y el valor del arte en la sociedad, entre otras características. Los movimientos artísticos que encajan en esta nueva época surgida a mediados y finales del siglo XX tienen lugar en diversos ámbitos, desde la pintura y escultura hasta el cine. En España, por causas evidentes, el posmodernismo explotó como una verdadera manifestación de contracultura y floreció con la fuerza y la provocación que la censura había estado reteniendo. En el seno de estas manifestaciones a lo largo de los años 80, emerge en el mundo cinematográfico un movimiento trasgresor que buscaba darle voz a lo silenciado durante años, desde una estética diferente y a través de temáticas como la sexualidad, las drogas o la identidad sexual, entre otras. En definitiva, un cine posmoderno que construyó los cimientos para el progreso de las imágenes en la gran pantalla y la expresión de ideas y sentimientos previamente reprimidos.

Hablar de posmodernismo en el cine español conlleva inevitablemente hablar de Pedro Almodóvar. Un director de cine que desde sus raíces rurales ha llegado a convertirse en un icono de la movida madrileña y del verdadero significado del cine posmoderno; Un punto de inflexión para la historia del cine y un impulso hacia el arte contemporáneo en su país.

Desde los años 80, este director manchego no ha cesado de evolucionar en todos los ámbitos, forjándose a través del arduo camino de la profesión cinematográfica, una reputación y una firma reconocible en muchos rincones del mundo.

No obstante, los films de Pedro Almodóvar van mucho más allá de la movida madrileña por la que es reconocido, algo que José Luis Sánchez Noriega quiere hacer ver al lector a través de un análisis más abierto repleto de reflexiones para enriquecer la idea sobre este renombrado director español, yendo más allá de la crítica y la simple interpretación. 
En su libro "Universo Almodóvar. Estética de la pasión en un cineasta posmoderno", este profesor de Historia del Cine y del Audiovisual en la Complutense de Madrid, se sume en la ardua tarea de desgranar el mundo de Pedro Almodóvar con un ensayo a modo de bosquejo que intente reflexionar sobre la longeva y rica trayectoria de este director español, dejando libertad al lector y espectador para interpretar el cine de Almodóvar. En este sentido, José Luis Sánchez Noriega establece una serie de bloques con temáticas definidas llevando a cabo una aproximación transversal del universo Almodóvar, entre los análisis de las 20 películas del director, desde las primeras como "Carne trémula" o "La ley del deseo" hasta las más recientes como "Amantes pasajeros" o "Julieta".

En una primera introducción, el escritor plasma su intención de sobrevolar los mosaicos que forman la tesela del cine de Almodóvar, teniendo como premisas principales la "estética de la pasión" y "cineasta posmoderno". A esto añade dos reflexiones muy interesantes, que él denomina complementarias. La primera sobre la posible definición de Almodóvar como “creyente de la imagen”, más que de la realidad, dado que "dedica su esfuerzo a la puesta en escena, la ambientación, la construcción visual, el montaje, la interpretación de los actores... para poner en pie un relato autosuficiente". (Sánchez Noriega, 2017). Por otra parte, está la cuestión sobre la construcción de un mundo propio a través de sus obras cinematográficas, sustentando una cosmovisión que da personalidad al director y que al ver sus films sin necesidad de saber quién lo dirige, se identifique a través de sus recurrentes temáticas, estéticas e incluso actrices o actores.

En este viaje transversal por el mundo de Pedro Almodóvar, José Luis Sánchez Noriega establece 8 grandes bloques: "Personalidad del cineasta"; "Películas"; "Forma fílmica"; "El mundo del cine"; "Identidad, género y sexualidad"; "Temas centrales de la filmografía" y "Cultura y sociedad". Dentro de esa gran división aparecen subsecciones como "Actrices/actores" donde nombra a los más recurrentes: Penélope Cruz, Antonio Banderas, Victoria Abril, etc. entre otros muchos, destacando su preferencia por las mujeres en su cinematografía que incluso le ha valido la denominación popular de "director de mujeres" o a las actrices la de "chicas Almodóvar". También establece otras secciones como "cameos", "cine en el cine" o "Madrid". Entre las múltiples clasificaciones que establece el escritor, se podrían destacar dentro de "Identidad, género y sexualidad", las temáticas como la homosexualidad, el deseo - que incluso da nombre a la productora creada por el propio director y su hermano Agustín -, la 
identidad o la sexualidad. Esta última está siempre presente en sus films de una manera u otra, presentándolo como un mundo misterioso por descubrir, con tintes provocadores incluso con tabúes como el incesto.

En definitiva, José Luis Sánchez Noriega presenta el universo Almodóvar totalmente desgranado y organizado desde un visionado inteligente, de manera que el lector pueda conocer la evolución y la trayectoria de este gran director español, pero dejando libertad al mismo de interpretar su filmografía. "El espectador se apropia del film desde la insobornable libertad y soberanía que requiere la aprehensión de la obra artística". (Sánchez Noriega, 2017).

En este libro, también tiene cabida una comparación entre el gran Luis Buñuel y el presente director - el cual además ha bebido del primero -, como directores similares pero separados por medio siglo. Ambos tienen un diálogo subterráneo entre su filmografía con obras provocadoras y alternativas, que Almodóvar adereza con un tono más "gamberro" y "festivo". Ambos retratan el realismo español radicalizado, pero Pedro Almodóvar a diferencia de Buñuel, elimina todo juicio moral sobre la sexualidad.

Pedro Almodóvar es dibujado en este libro "Universo Almodóvar. Estética de la pasión en un cineasta posmoderno", como un director de la posmodernidad que destaca por su hibridación y reescritura de géneros, la ironía, la sexualidad natural y neorrealismo, junto a la intertextualidad y el metacine, entre otras muchas características destacadas y desarrolladas por José Luis Sánchez Noriega.

Un dibujo con trazos difuminados de una larga carrera de experiencias y evoluciones que permite al lector crear en su mente una delineación más precisa, dependiendo de una interpretación independiente y libre sobre el gran mosaico que conforma el “Universo Almodóvar". 